\title{
Maoecrystal V: A formidable synthetic challenge
}

\author{
TARUN KUMAR BEHERA, SK. NURUL ISLAM and VISHWAKARMA SINGH* \\ Department of Chemistry, Indian Institute of Technology Bombay, Mumbai 400 076, India \\ e-mail: vks@chem.iitb.ac.in
}

MS received 2 August 2013; revised 11 September 2013; accepted 17 September 2013

\begin{abstract}
Nature continues to be a rich source of bio-active compounds that often provide the lead for drug development. Isolation and characterization of maoecrystal V, a C19 terpenoid, having potent and selective cytotoxicity towards HeLa cells was recently reported. Unusually complex pentacyclic molecular structure, presence of spirofused rings and several stereogenic centres posed a great synthetic challenge. In this short review, efforts made towards synthesis of maoecrystal $\mathrm{V}$ are presented.
\end{abstract}

Keywords. Maoecrystal V; synthesis; Diels-Alder reaction; dearomatization.

\section{Introduction}

There is continuing search for biologically active compounds from various types of natural sources as it often provides a lead or inspiration for drug discovery and development. ${ }^{1-4}$

Investigations on plants and shrubs that are used in folk medicine often lead to isolation of interesting compounds with potent biological properties. Isodon eriocalyx (Dunn.) Hara, a herb widely distributed in China and used as folk medicine for treatment of various kinds of ailments, is known to be a rich source of biologically active diterpenoids. ${ }^{5}$ Maoecrystal V (figure 1) was isolated from the leaves of this plant by Sun and coworkers. ${ }^{6}$ The structure of maoecrystal V was established by detailed spectroscopic methods and confirmed with the help of a single-crystal structure determination. ${ }^{6}$ Maoecrystal $\mathrm{V}$ exhibits a highly remarkable inhibitory activity towards $\mathrm{HeLa}$ cells at very low concentrations $\left(\mathrm{IC}_{50}=0.02 \mathrm{mg} / \mathrm{ml}\right.$; cis-platin $\mathrm{IC}_{50}=$ $0.99 \mathrm{mg} / \mathrm{mL}$ ). Potent biological activity and unusually complex structure of maoecrystal $\mathrm{V}$ has stimulated intense interest in its synthesis.

Presence of a bridged bicyclo[2.2.2] octanone ring annulated with a lactone ring that is spiroannulated with a six-membered enone and a strained five-membered ether in a highly unusual fashion, and several quaternary centres in molecular structure of maoecrystal V

*For correspondence poses a formidable synthetic challenge. Several leading research groups undertook this challenge, ${ }^{7-20}$ however, only two groups have succeeded in the synthesis of maoecrystal $\mathrm{V}$ since its isolation a decade ago. Yang and co-workers reported the first total synthesis of $\mathbf{1}$ in $2010 .{ }^{19}$ Danishefsky and co-workers unravelled synthesis of maoecrystal in $2012 .{ }^{20}$

We wish to highlight the synthetic approaches and studies directed towards synthesis of maoecrystal V in this short review in order to give an overview that would provide further stimulation to generate new ideas and chemistry. We would first summarize various approaches and model studies; total synthesis will be presented towards the end.

\section{Studies towards synthesis of maoecrystal $\mathrm{V}$}

Yang and co-workers reported synthesis of tetracyclic framework of maoecrystal-containing lactone ring. ${ }^{7}$ Oxidative dearomatization and intramolecular DielsAlder reaction are the key features of their design and approach. ${ }^{7}$ They employed aryl lead compound $\mathbf{3}$, prepared from aryl boronic acid 2, for coupling with active methylene compound. Thus, treatment of 2 with $\mathrm{Pb}(\mathrm{OAc})_{4}$ and $\mathrm{Hg}(\mathrm{OAc})_{2}$ gave aryl lead compound 3, which upon oxidative arylation ${ }^{21}$ with 2carboethoxycyclohexanone followed by acid catalysed removal of methoxymethyl (MOM) ether furnished tricyclic compound $\mathbf{4}$. Reduction of the ester group and subsequent esterification with acrylic acid gave hemiketal 5. Wessely oxidation ${ }^{22}$ of $\mathbf{5}$ with $\mathrm{Pb}(\mathrm{OAc})_{4}$ gave a diastereomeric mixture of embellished cyclohexa-2,4dienone 6 that underwent intramolecular Diels-Alder 


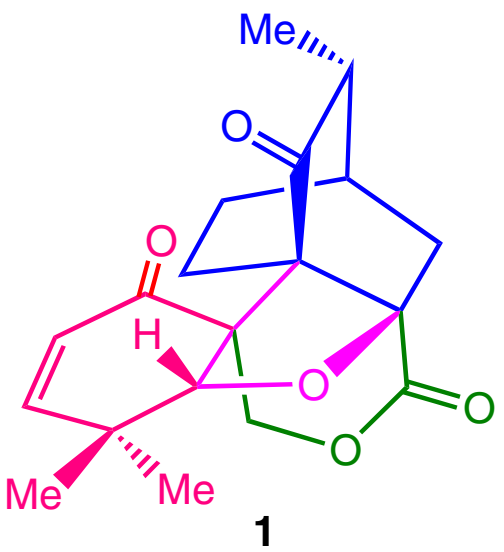

Figure 1. Structure of maoecrystal V.

reaction to furnish a mixture of adduct $\mathbf{7 a}, \mathbf{b}$. Reduction of 7a,b with $\mathrm{H}_{2}$, Pd-C followed by $\mathrm{SmI}_{2}$ furnished tetracyclic compounds 8a,b, respectively (scheme 1).

Subsequently, Baran's group disclosed their approach towards maoecrystal $\mathrm{V}$ that features oxidative dearomatization via Wessely oxidation and intramolecular Diels-Alder reaction as key steps. ${ }^{8}$ Coupling of keto-enol 9 with aryl bismuth chloride $\mathbf{1 0}$ gave the precursor 11 that was converted into $\mathbf{1 2}$ having dienophilic moiety. Hydrolysis of MOM group led to the formation of lactol 13. Interestingly, oxidative dearomatization of $\mathbf{1 3}$ with lead tetracetate gave the dienone acetate 14 as a mixture of diastereoisomers. Intramolecular Diels-Alder reaction in $\mathbf{1 4}$ furnished tetracyclic adduct 15 that upon hydrolysis of tert-butyl dimethylsilyl (TBS) group gave alcohol 16. Reduction of the double bond and acetate group gave 17 (scheme 2) having tetracyclic framework of maoecrystal $\mathrm{V}$ (scheme 2). ${ }^{8}$

Danishefsky and co-workers described their approach towards creation of tetracyclic network of maoecrystal $\mathrm{V}$ that involved reductive dearomatization and intramolecular Diels-Alder reaction as key elements. ${ }^{9}$ Palladium-

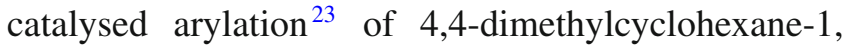
3-dione 18 with $m$-bromoanisole 19 followed by oalkylation gave compound $\mathbf{2 0}$ that was elaborated into stannate 21. Treatment of $\mathbf{2 1}$ with BuLi furnished

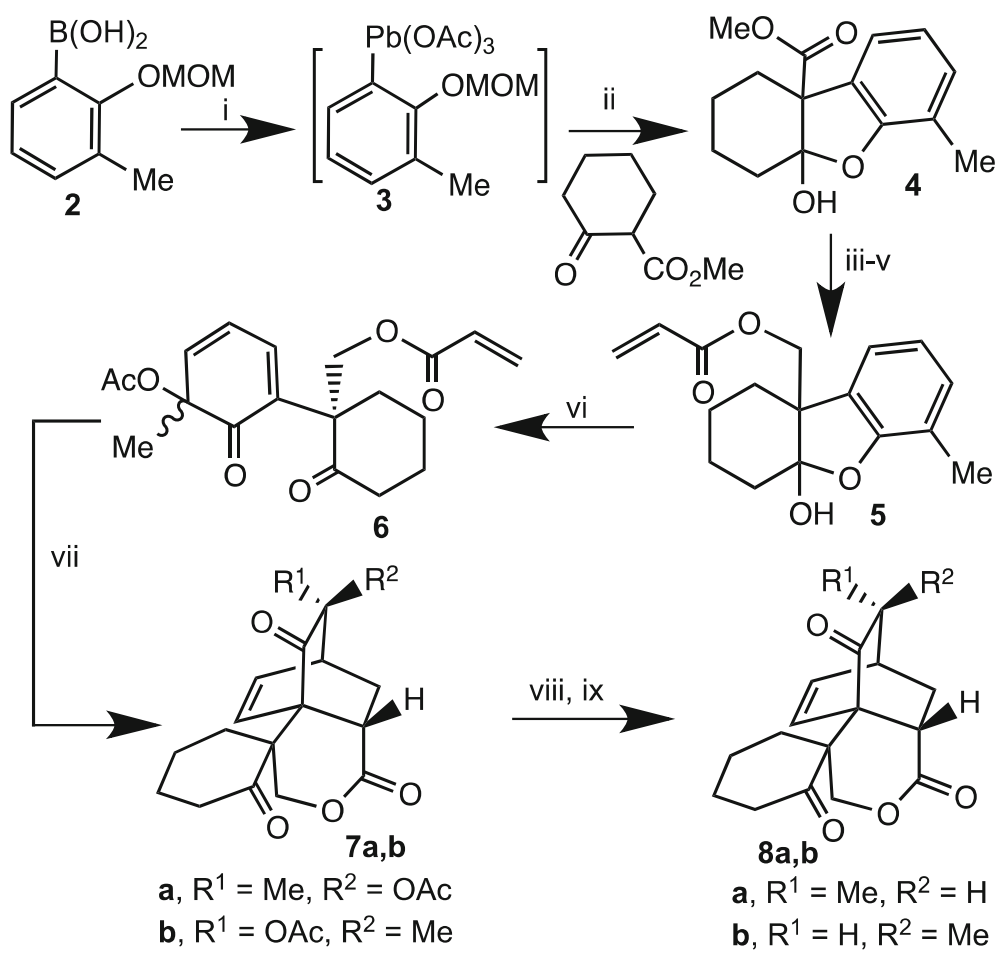

Reagents/conditions: i, $\mathrm{Pb}(\mathrm{OAc})_{4}, \mathrm{Hg}(\mathrm{OAc})_{2}, \mathrm{CHCl}_{3}, 60^{\circ} \mathrm{C}$; ii, Pyridine, $\mathrm{CHCl}_{3}$, then $\mathrm{H}^{+}$; iii TMSCl, imidazole, $\mathrm{CH}_{2} \mathrm{Cl}_{2}, 0^{\circ} \mathrm{C}$; iv, DIBAL-H, $\mathrm{CH}_{2} \mathrm{Cl}_{2}$, $-78^{\circ} \mathrm{C}$ to rt, then $\mathrm{HCl}(85 \%)$; v, acrylic acid, EDCl, DMAP (70\%); vi, $\mathrm{Pb}(\mathrm{OAc})_{4}$, acetic acid $(92 \%)$; vii, $130^{\circ} \mathrm{C}$, Toluene $(7 \mathrm{a}: 88 \%, 7 \mathrm{~b}: 82 \%)$; viii, Pd-C, $\mathrm{H}_{2}$ (92\% from $7 \mathrm{a}, 90 \%$ from $\left.7 \mathrm{~b}\right)$; ix, Sml 2 , THF, $t \mathrm{BuOH}(68 \%$ from $7 \mathbf{a}, 65 \%$ from $7 \mathbf{b})$.

Scheme 1. Yang's approach to tetracyclic core. 


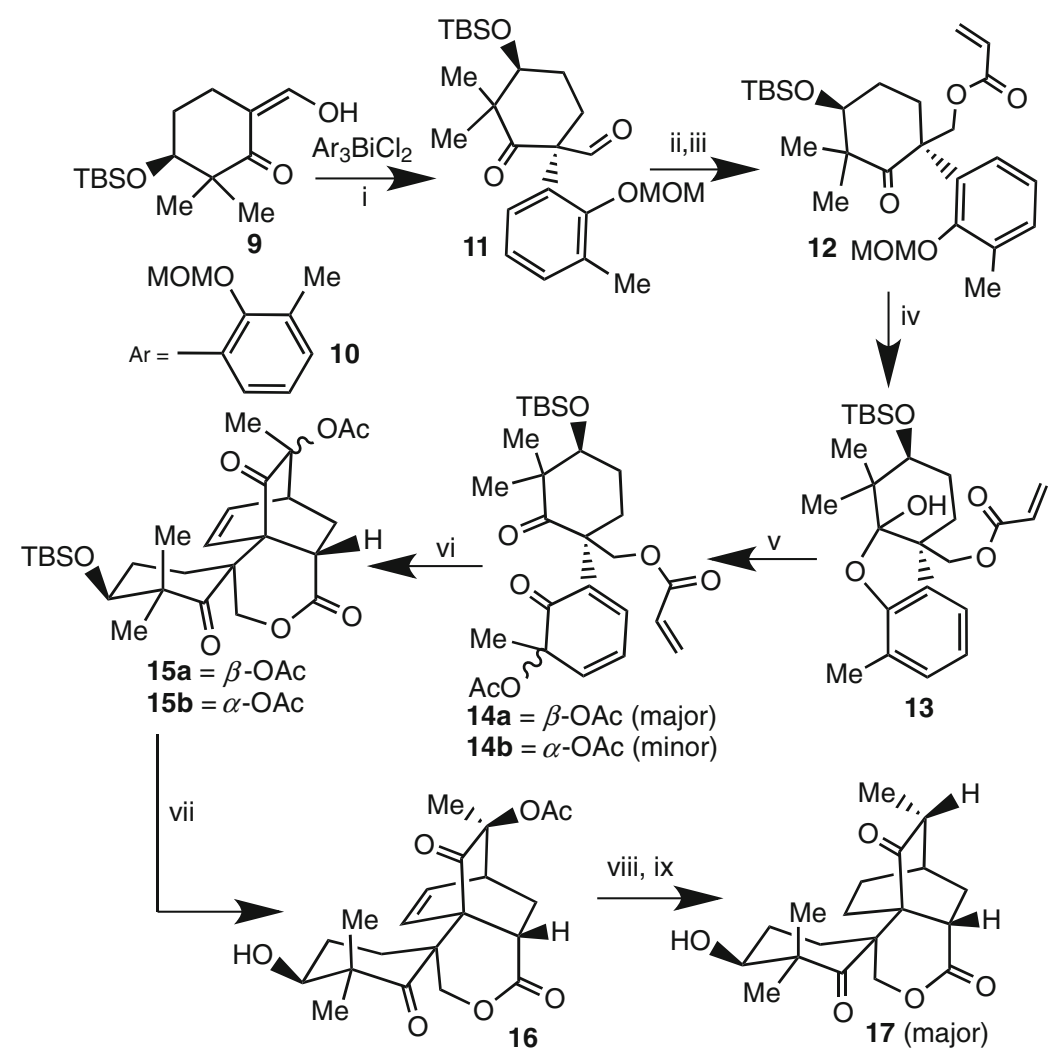

Reagents/conditions: i, $\mathrm{Ar}_{3} \mathrm{BiCl}_{2}$, DBU, toluene $(67 \%)$; ii, $\mathrm{Li}(t \mathrm{BuO})_{3} \mathrm{AlH}$, THF (72\%); iii, acryloyl chloride, DIEPA, DMAP, $\mathrm{CH}_{2} \mathrm{Cl}_{2},-78^{\circ} \mathrm{C}(69 \%)$; iv, Trifluoroacetic acid (65\%); v, $\mathrm{Pb}(\mathrm{OAc})_{4}, \mathrm{AcOH}(81 \%) ; \mathrm{vi}, 165^{\circ} \mathrm{C}, \mathrm{DCB}$, BHT $(79 \%$ for $15 a, 69 \%$ for $15 b)$; vii, $\mathrm{BF}_{3} \mathrm{OEt}_{2}, \mathrm{CH}_{2} \mathrm{Cl}_{2}(82 \%)$; viii, $\mathrm{H}_{2}$, $\mathrm{Pd}-\mathrm{C}(93 \%)$; ix, $\mathrm{Sml}_{2}, \mathrm{MeOH}, \mathrm{THF} 0^{\circ} \mathrm{C}(76 \%)$.

Scheme 2. Synthesis of tetracyclic core by Baran's group.

compound 22. Birch reduction of $\mathbf{2 2}$ followed by hydrolysis of enolether and isomerization gave bicyclic compound $\mathbf{2 4}$ that was elaborated into the intermediate $\mathbf{2 5}$ containing diene and dienophilic moieties for the subsequent intramolecular Diels-Alder reaction. Heating 25 furnished tetracyclic compound $\mathbf{2 6}$ containing spiro-annulated lactone ring. The endo-selectivity during cycloaddition was however, governed by carbomethoxy group. Hydrolysis of enol ether moiety gave the ketone $\mathbf{2 7}$ having tetracyclic core of maoecrystal V (scheme 3).

Nicolaou and co-workers reported the synthesis of a highly functionalized maoecrystal $\mathrm{V}$ core structure, wherein intramolecular Diels-Alder reaction has been employed to generate bridged tetracyclic structure having five-membered ring ether and oxidative dearomatization of phenol to create functionalized cyclohexane ring and the lactone moiety (scheme 4). ${ }^{10}$ Thus, palladium-mediated decarboxylative coupling ${ }^{24}$ of $\mathbf{2 8}$ with cyclohexenone gave the arylated enone 29 that was converted into $\mathbf{3 0}$. Reaction of $\mathbf{3 0}$ with $\mathbf{3 1}$ followed by elimination led to compound $\mathbf{3 2}$ that upon treatment with tert-butyldimethylsilyltriflate (TBSOTf) generated the triene 33. Intramolecular Diels-Alder reaction in 33 followed by hydrolysis of TBS ether gave tetracyclic keto-ester $\mathbf{3 4}$ containing major structural features of maoecrystal V. Oxidative dearomatization of phenolic ring in $\mathbf{3 4}$ followed by hydrogenation gave the keto-acetal 35. Hydrolysis of the ester group and subsequent treatment of the resulting carboxylic acid with chloroiodomethane in presence of $\mathrm{KO} t \mathrm{Bu}$ furnished the pentacyclic compound $\mathbf{3 7}$ in a neat manner (scheme 4).

Singh and co-workers developed a route to tricyclic framework having a lactone ring. ${ }^{11}$ They relied on oxidative dearomatization of o-hydroxymethylphenol and intramolecular cycloaddition of 6,6-spiroepoxycyclohexa-2,4-dienone (scheme 5). ${ }^{11}$ Thus, o-hydroxymethylphenol 39 containing acryloyl moiety, readily available from 38, was oxidized with aq. $\mathrm{NaIO}_{4}{ }^{25}$ to give the adduct $\mathbf{4 2}$ as a result of intramolecular cycloaddition in $\mathbf{4 0}$ and the dimer $\mathbf{4 1}$ arising due to intermolecular reaction between cyclohexadienone moiety of $\mathbf{4 0}$. 


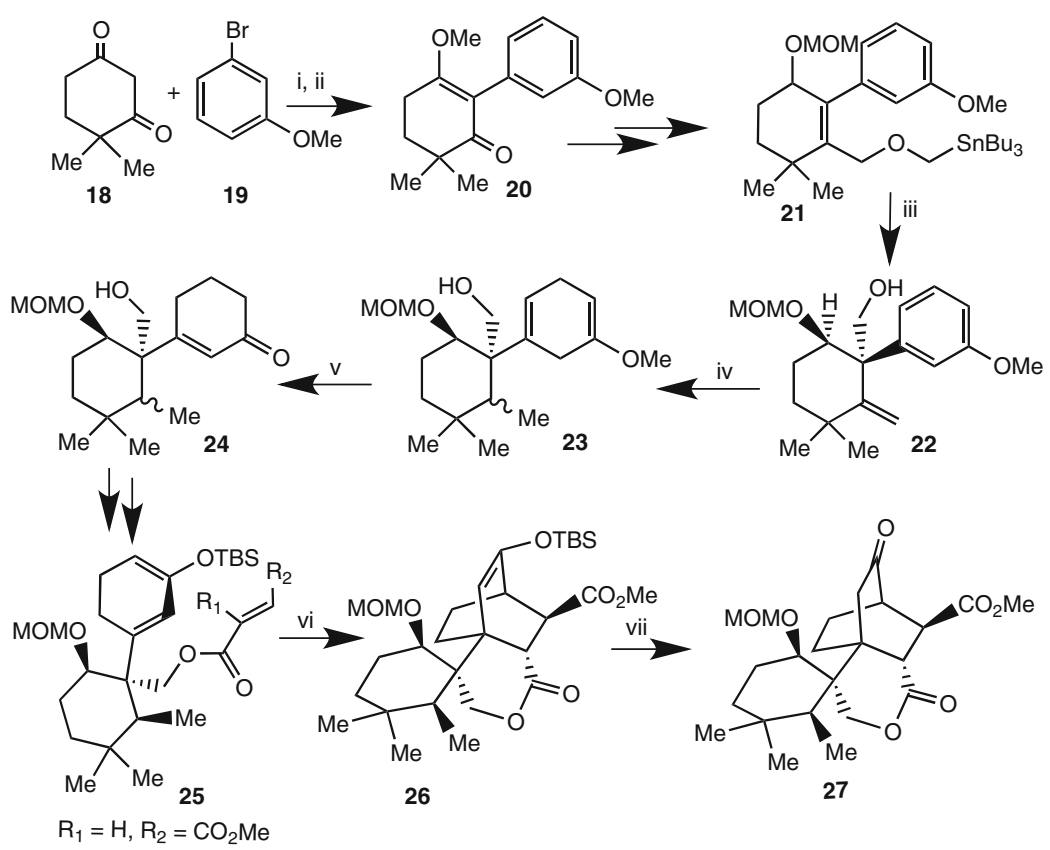

Reagents/conditions: i, $\mathrm{Pd}(\mathrm{OAc})_{2}$, 2-di-tbutylphosphino-2'-methylbiphenyl, $\mathrm{K}_{3} \mathrm{PO}_{4}, \mathrm{THF}, 80^{\circ} \mathrm{C}(91 \%)$; ii, $\mathrm{TMSCHN}_{2}$, Hunig's base, $\mathrm{CH}_{3} \mathrm{CN}-\mathrm{MeOH}, 6 \mathrm{~h}$,

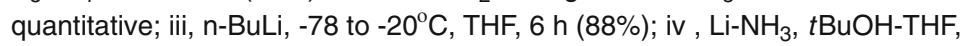
-78 to $-33^{\circ} \mathrm{C} ; \mathrm{v}, 1 \mathrm{~N} \mathrm{HCl}, 0^{\circ} \mathrm{C}$, THF-MeOH, $8 \mathrm{~h}(78 \%)$; vi, $180^{\circ} \mathrm{C}$, toluene, $12 \mathrm{~h}$; vii, TBAF, $0^{\circ} \mathrm{C}$, THF (48\% two steps).

Scheme 3. Danishefsky's approach to tetracyclic compound 27.

Alternatively, adduct $\mathbf{4 2}$ was also obtained in excellent yield by thermal activation of dimer $\mathbf{4 1}$ via a tandem retro Diels-Alder/Diels-Alder cycloaddition. Adduct $\mathbf{4 2}$ was readily manipulated to give tricyclic compound 44 that upon hydrogenation afforded 45 containing tricyclic core of maoecrystal V (scheme 5).

Thomson and co-workers devised an approach to tetracyclic framework of maoecrystal $\mathrm{V}$ that employed Nazarov cyclization ${ }^{26}$ to make tetracyclic precursorcontaining diene moiety and intermolecular DielsAlder reaction to create bridged ring system of maoecrystal $\mathrm{V}$ as shown in scheme 6 . Thus, treatment of compound 46 with $\mathrm{FeCl}_{3}$ generated spiroannulated dienone $\mathbf{4 7}$ that upon reduction of ketone followed by cycloaddition of the resulting alcohol with nitroethylene gave tetracyclic compound 48. Treatment of $\mathbf{4 8}$ with $\mathrm{KOH}$ followed by Jones oxidation gave compound 49 that upon oxidation of methylene group of the fivemembered ring afforded keto-alcohol 50. Reduction of enone $\mathbf{5 0}$ to generate saturated ketone proved to be unpredictable. However, reduction of $\mathbf{5 0}$ with $\mathrm{H}_{2}$ on Pd-C gave highly unexpected compound $\mathbf{5 1}$ containing cyclopropane ring as a result of displacement of nitro group. Oxidative cleavage of keto-alcohol followed by reduction with $\mathrm{NaBH}_{4}$ furnished pentacyclic compound 52 (scheme 6). ${ }^{12}$
Trauner's approach to tetracyclic framework of maoecrystal $\mathrm{V}$ is depicted in scheme $7 .{ }^{13}$ Intramolecular aldol condensation in $\mathbf{5 3}$ followed by protection of the resulting alcohol gave $\mathbf{5 4}$ having bridged bicyclo[2.2.2] octane ring system of maoecrystal. Bicyclic compound 54 was elaborated into aldehyde 55 with the hope to introduce a prenyl chain. Unfortunately, attempts to perform reverse prenylation using various reagents failed. Therefore, $\mathbf{5 4}$ was treated with lithiated trimethylsilyl acetylene that furnished the adduct 56 which was converted into vinyl lactone 57. Further elaboration of $\mathbf{5 7}$ led to the diol $\mathbf{5 8}$ that upon ozonolysis furnished tetracyclic compound $\mathbf{5 9}$ (scheme 7).

In continuation of their studies towards synthesis of maoecrystal V, Danishefsky and Peng reported synthesis of pentacyclic core $\mathbf{6 8}$ (scheme 8). ${ }^{14}$ Alkylation of diene $\mathbf{6 0}$ with 3-chlorocyclohexenone gave the enone-ester $\mathbf{6 1}$ that was transformed into compound 62 that upon intramolecular Diels-Alder reaction gave tetracyclic compound 63. Regioselective functionalization of conjugated $\mathrm{C}=\mathrm{C}$ bond furnished hydroxylactone 64. Treatment of $\mathbf{6 4}$ with $m$-CPBA gave epoxide that upon reaction with $p$-toluenesulphonic acid furnished hydroxyl ether $\mathbf{6 5}$. However, the stereochemistry at the newly generated centre was incorrect. Hence, compound 65 was converted into enolether $\mathbf{6 6}$. 


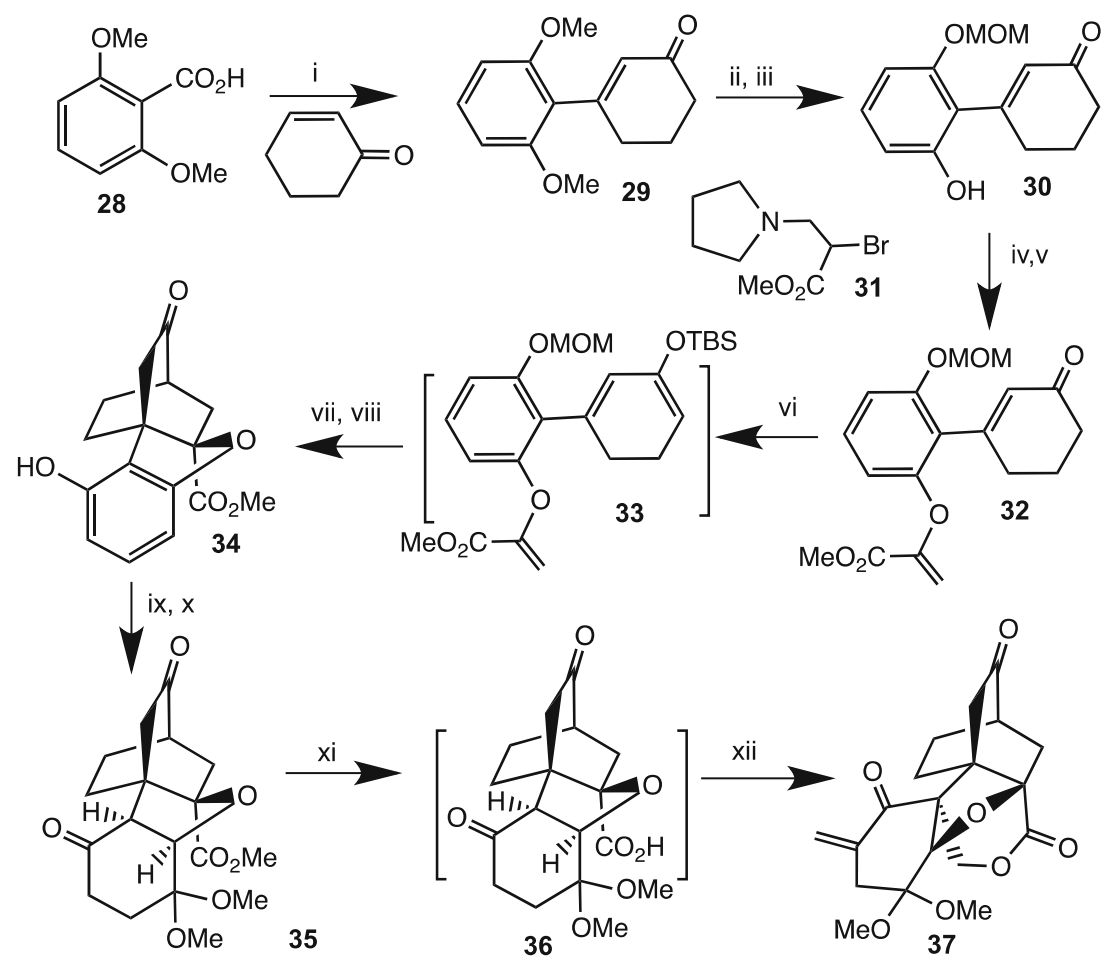

Reagents/conditions: i, $\mathrm{Pd}(\mathrm{TFA})_{2}, \mathrm{Ag}_{2} \mathrm{CO}_{3}, \mathrm{DMF} / \mathrm{DMSO}, 80^{\circ} \mathrm{C}$, 3 h (89\%); ii, $\mathrm{BBr}_{3}, \mathrm{CH}_{2} \mathrm{Cl}_{2},-78$ to $0^{\circ} \mathrm{C}, 2 \mathrm{~h}(98 \%)$; iii, $\mathrm{NaH}, \mathrm{MOMCl}$, THF, $0^{\circ} \mathrm{C}, 2$ h $(56 \%)$; iv, $\mathrm{NaH}, \mathrm{THF}, 31,0$ to $23^{\circ} \mathrm{C} ; \mathrm{v}, \mathrm{Na}_{2} \mathrm{CO}_{3}$, Mel, $\mathrm{MeOH}$, reflux, (57\% two steps); vi, TBSOTf, $\mathrm{ET}_{3} \mathrm{~N}, \mathrm{CH}_{2} \mathrm{Cl}_{2} ;$ vii, $\mathrm{K}_{2} \mathrm{CO}_{3}$, hydroquinone, toluene reflux, then aq. $\mathrm{HCl}(50 \%$, both steps); viii, $6 \mathrm{~N}$ $\mathrm{HCl}$, EtOH-CHCl 3 , reflux, $3 \mathrm{~h}(83 \%)$; ix, PIFA, $\mathrm{KHCO}_{3}, \mathrm{MeOH}, 0$ to $23^{\circ} \mathrm{C}$ $(83 \%) ; x, \mathrm{H}_{2}, \mathrm{Pd}-\mathrm{C}, \mathrm{EtOH}, 23^{\circ} \mathrm{C}, 10 \mathrm{~h},(66 \%) ; \mathrm{xi}, 1 \mathrm{~N} \mathrm{NaOH}, \mathrm{EtOH}$, reflux, then $1.0 \mathrm{~N}$ aq. $\mathrm{HCl}$; $x i i, \mathrm{ClCH}_{2} \mathrm{I}, \mathrm{KO} t \mathrm{Bu}, 18 \mathrm{C}_{6}, \mathrm{THF}, 23^{\circ} \mathrm{C}, 3 \mathrm{~h}$ (42\% both steps).

Scheme 4. Nicolaou's synthesis of pentacyclic core.

Reaction of $\mathbf{6 6}$ with dimethyldioxirane followed by $\mathrm{BF}_{3}$ furnished the pentacyclic compound $\mathbf{6 8}$ having correct stereochemistry at C5 via stereospecific rearrangement of epoxide 67.

Zakarian and $\mathrm{Gu}$ developed ${ }^{15}$ a strategy for the synthesis of tetracyclic network of maoecrystal V containing five-membered ring ether and lactone moiety that employed rhodium-catalysed $\mathrm{CH}$ functionalization, ${ }^{26}$ oxidative dearomatization of appropriately substituted dihydrobenzofuran and intramolecular DielsAlder reaction (scheme 9) as key features. Thus, sesamol 69 was converted into diazoester 70. Rhodiumcatalysed reaction of $\mathbf{7 0}$ gave compound $\mathbf{7 1}$ that upon alkylation and reduction of ester group furnished the alcohol 72. Treatment of $\mathbf{7 2}$ with methyl magnesium bromide led to the cleavage of methylidine group to give the key precursor 73. Oxidative dearomatization of $\mathbf{7 3}$ gave cyclohexadienone ketal $\mathbf{7 4}$ that was sufficiently stable to permit further transformation. The hydroxymethyl group in $\mathbf{7 4}$ was derivatized to give the acrylate $\mathbf{7 5}$ that upon intramolecular Diels-Alder reaction furnished tetracyclic compound $\mathbf{7 6 .}$

Continuing with their studies, Chen and co-workers further reported the synthesis of pentacyclic compound 82 from the readily available precursor $\mathbf{7 7}$ (scheme 9). ${ }^{16}$ Thus, the dienone acetal $\mathbf{7 7}$ was elaborated into compound $\mathbf{7 8}$ in a few steps. Hydrolysis of acetal moiety in $\mathbf{7 8}$ followed by olefination with Tebbe's reagent and subsequent Simon-Smith readily furnished $\mathbf{7 9}$ that was converted into diketoester $\mathbf{8 0}$ after removal of benzyl groups, oxidation and reduction of spirocyclopropane ring. Oxidation of cyclohexanone ring followed by hydrolysis of ester group gave enone $\mathbf{8 1}$ that upon treatment with chloroiodomethane in the presence of KOtBu furnished pentacyclic compound 82 (scheme 10).

In continuation their studies, Thomson and coworkers recently reported synthesis of compound $\mathbf{8 8}$ having tricyclic fragment of maoecrystal $\mathrm{V}$ from epoxyacetal 83 (scheme 11). ${ }^{17}$ Reaction of epoxy acetal 83 with methylmethacrylate in the presence of 


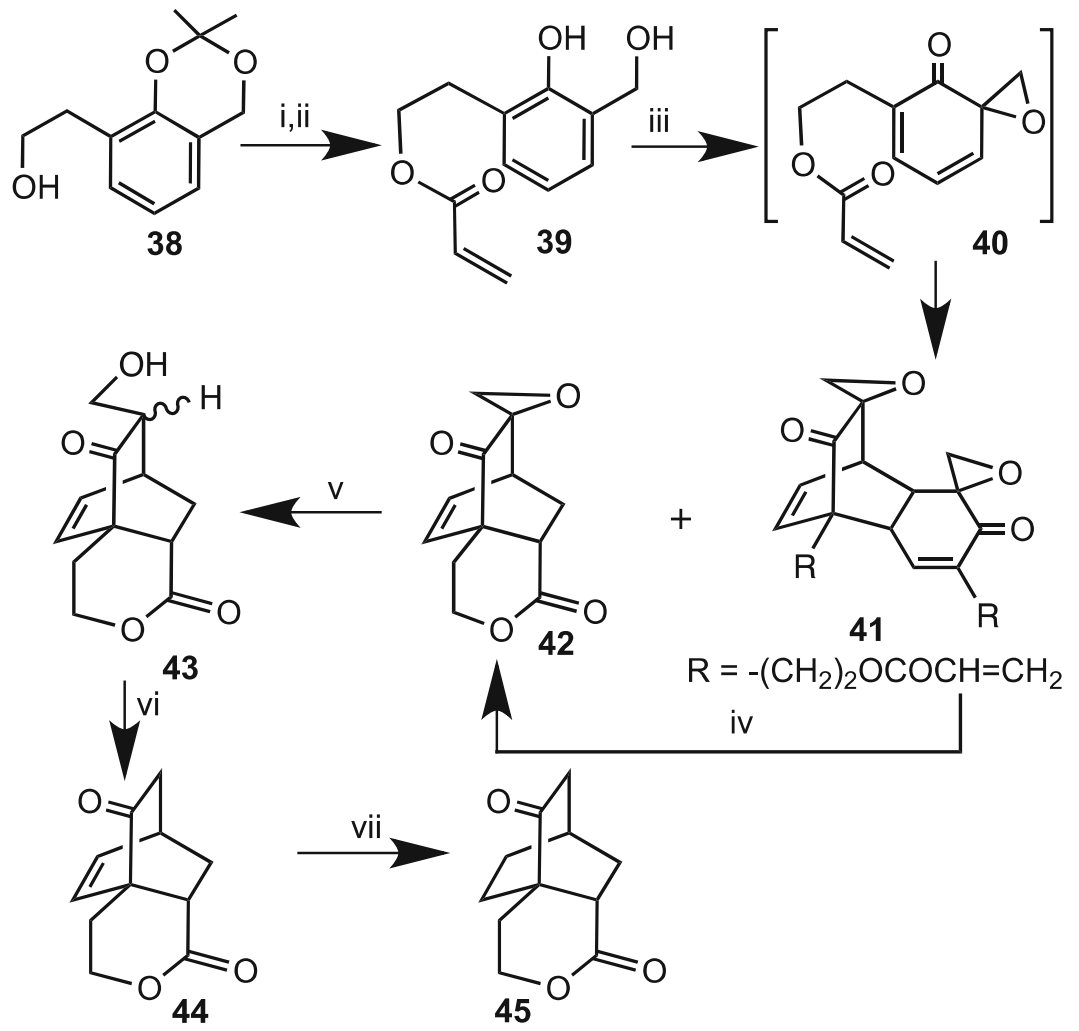

Reagents/conditions: i, acryloyl chloride, $\mathrm{CH}_{2} \mathrm{Cl}_{2}$, diispropyl ethyl amine, DMAP, 95\%; ii, aq. $\mathrm{HCl}$, THF, rt, (91\%); iii, aq. $\mathrm{NalO}_{4}, \mathrm{CH}_{3} \mathrm{CN}, 0^{\circ} \mathrm{C}$-rt (40\% for $42,42 \%$ for 41 ); iv, o-dichlorobenzene, $140^{\circ} \mathrm{C}(75 \%)$; v, $\mathrm{Zn}$, $\mathrm{NH}_{4} \mathrm{Cl}$, aq.MeOH, rt (93\%); vi, (a) Jones oxidation, (b) aq. THF, $\Delta(66 \%)$; vii, $\mathrm{H}_{2}, \mathrm{Pd}-\mathrm{C}, \mathrm{EtOH}(90 \%)$.

Scheme 5. Singh's route to tricyclic ketolactone.

$\mathrm{Cp}_{2}$ ( $\mathrm{Ti}(\mathrm{III}) \mathrm{Cl}$ gave the spirolactone 84 that upon $\alpha$ hydroxylation with $\mathrm{MoOPh}$ followed by protection furnished compound $\mathbf{8 5}$. Introduction of the double bond in cyclohexanone ring gave the enone 86. Treatment of 86 with TBAF gave 87 that underwent intramolecular oxa-Michael reaction to afford the tricyclic compound $\mathbf{8 8}$ containing five-membered ether ring.

Recently, Chisholm and co-workers reported a strategy towards synthesis of pentacyclic core structure involving a hetero-Diels-Alder reaction as a key step (scheme 12). ${ }^{18}$ The authors conceptualized that heteroDiels-Alder reaction in $\mathbf{9 7}$ would lead to tetracyclic compound 98 that may be elaborated into pentacyclic system of maoecrystal V. Thus, the tricyclic enone $\mathbf{9 0}$ was prepared from bicyclic keto-alcohol $\mathbf{8 9}$ in three steps. Michael addition of $\mathbf{9 1}$ on enone $\mathbf{9 0}$ furnished compound 92 that was converted into 94 . The enone 94 containing OPMB group was derivatized into compound 95 containing OBz group. Treatment of 95 with TIPSOTf furnished tricyclic dienol ether 96. Removal of benzoyl group and oxidation gave the key precursor 97. Unfortunately, compound 97 did not undergo the desired intramolecular hetero-Diels-Alder reaction to give $\mathbf{9 8}$ (scheme 12).

\section{Syntheses of maoecrystal V}

\subsection{Yang's synthesis}

Continued efforts by Yang and co-workers led to first total synthesis of $( \pm)$-maoecrystal $\mathrm{V}$ that manifested an outstanding planning and brilliant execution (schemes 13 and 14). ${ }^{19}$ Design of appropriate precursor endowed with most of the structural features of maoecrystal V such as lactone moiety and five-membered ring ether, oxidative dearomatization and intramolecular cycloaddition are the key features of their design. Thus, coupling of aryl lead compound 99 with 6,6dimethyl-2-carbomethoxycyclohex-4-enone $\mathbf{1 0 0}$ led to the precursor 101 that was converted into the diol 102 in stereoselective manner. The diol $\mathbf{1 0 2}$ was transformed into the diazo compound $\mathbf{1 0 3}$ that upon rhodiummediated insertion of carbenoid across $\mathrm{OH}$ bond 


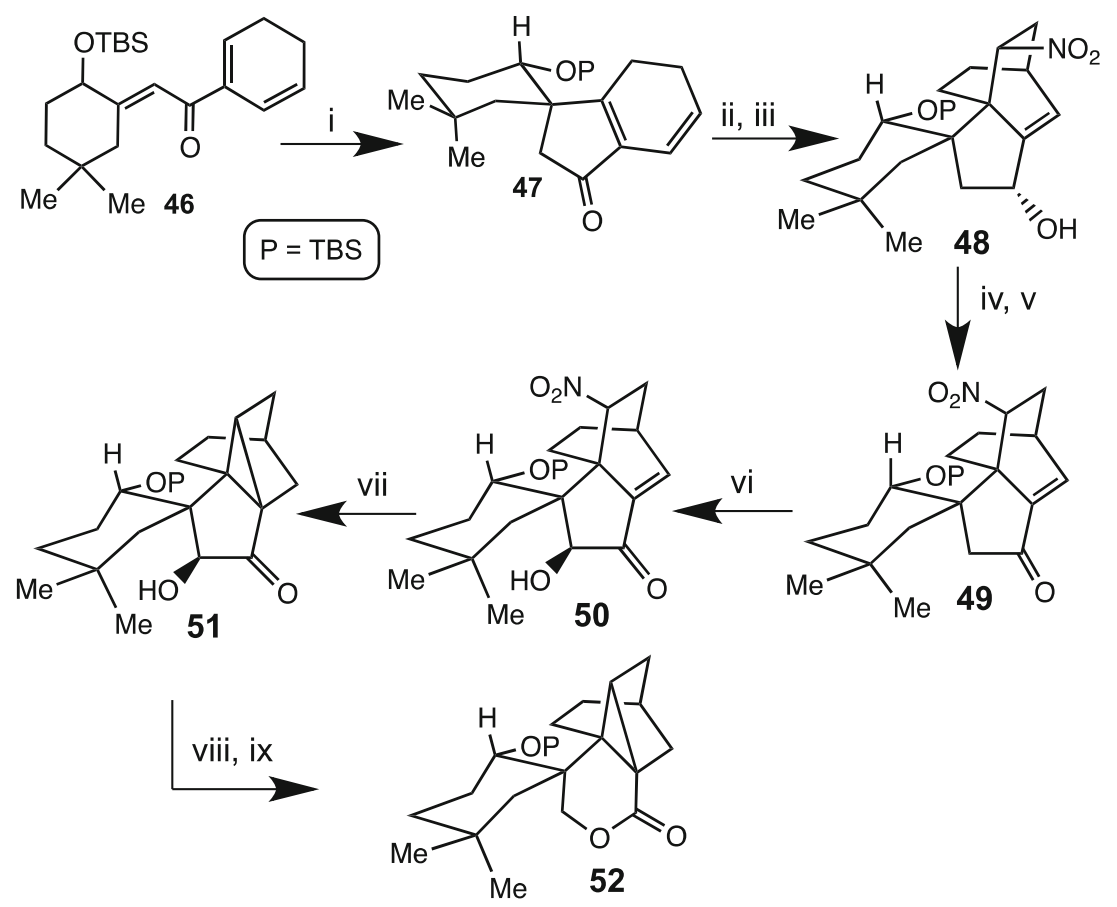

Reagents/conditions: i, $\mathrm{FeCl}_{3}(70 \%)$; ii, DIBAL-H; iii nitroethylene ( $44 \%$ for both steps); iv, $\mathrm{KOH}$; v, Jones oxidation $(86 \%$ for both steps); vi, HMDS, TMSI, $m$-CPBA ( $88 \%$ ); vii, Pd-C, $\mathrm{H}_{2}$ (71\%); viii, $\mathrm{H}_{5} \mathrm{IO}_{6}, \mathrm{MeOH} ; \mathrm{ix}, \mathrm{NaBH}_{4}(75 \%$ for both steps).

Scheme 6. Thomson's approach to tetracyclic lactone.

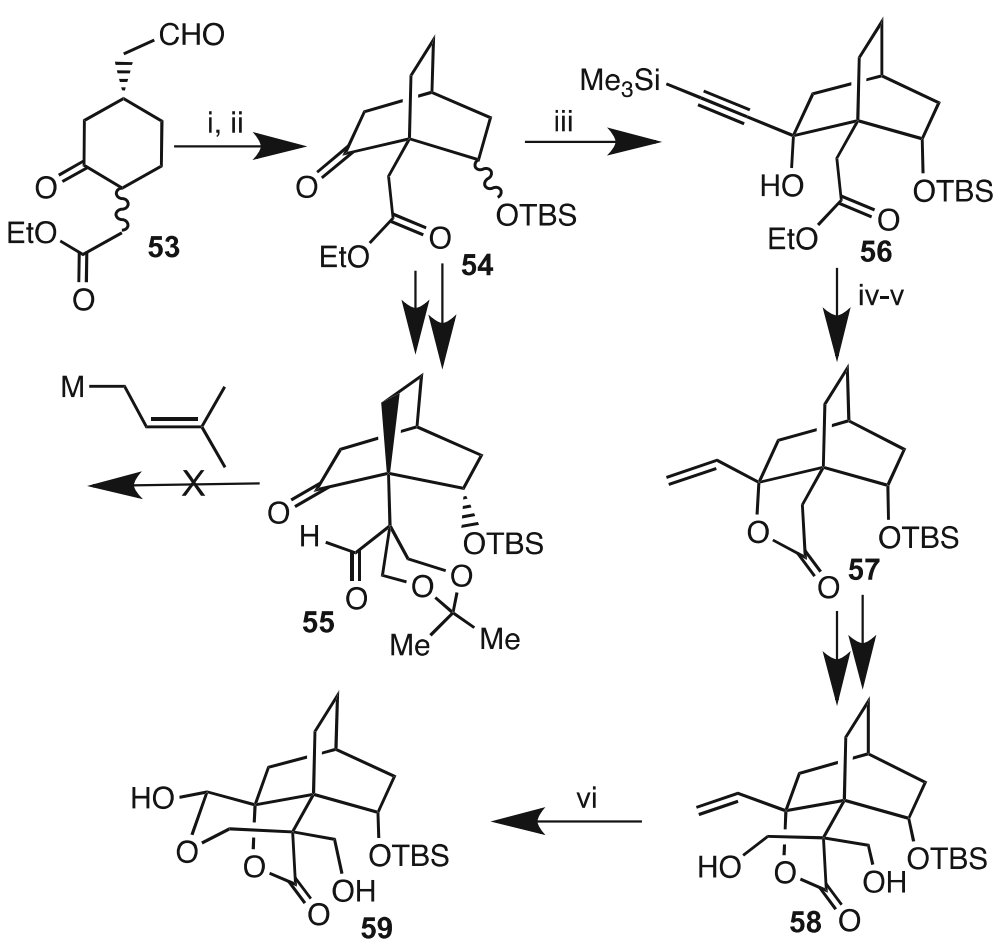

Reagents/conditions: i, $\mathrm{HCl}(56 \%)$; ii, TBSCI, $\operatorname{Im}(73 \%)$; iii,TMSA, BuLi (75\%); iv, $\mathrm{NaH}, 40^{\circ} \mathrm{C}(82 \%) ; \mathrm{v}$, $\mathrm{Pd} / \mathrm{CaCO}_{3} \cdot \mathrm{Py}, \mathrm{H}_{2}(96 \%)$; vi, $\mathrm{O}_{3}$, DMS (40\%).

Scheme 7. Trauner's route to tetracyclic core. 

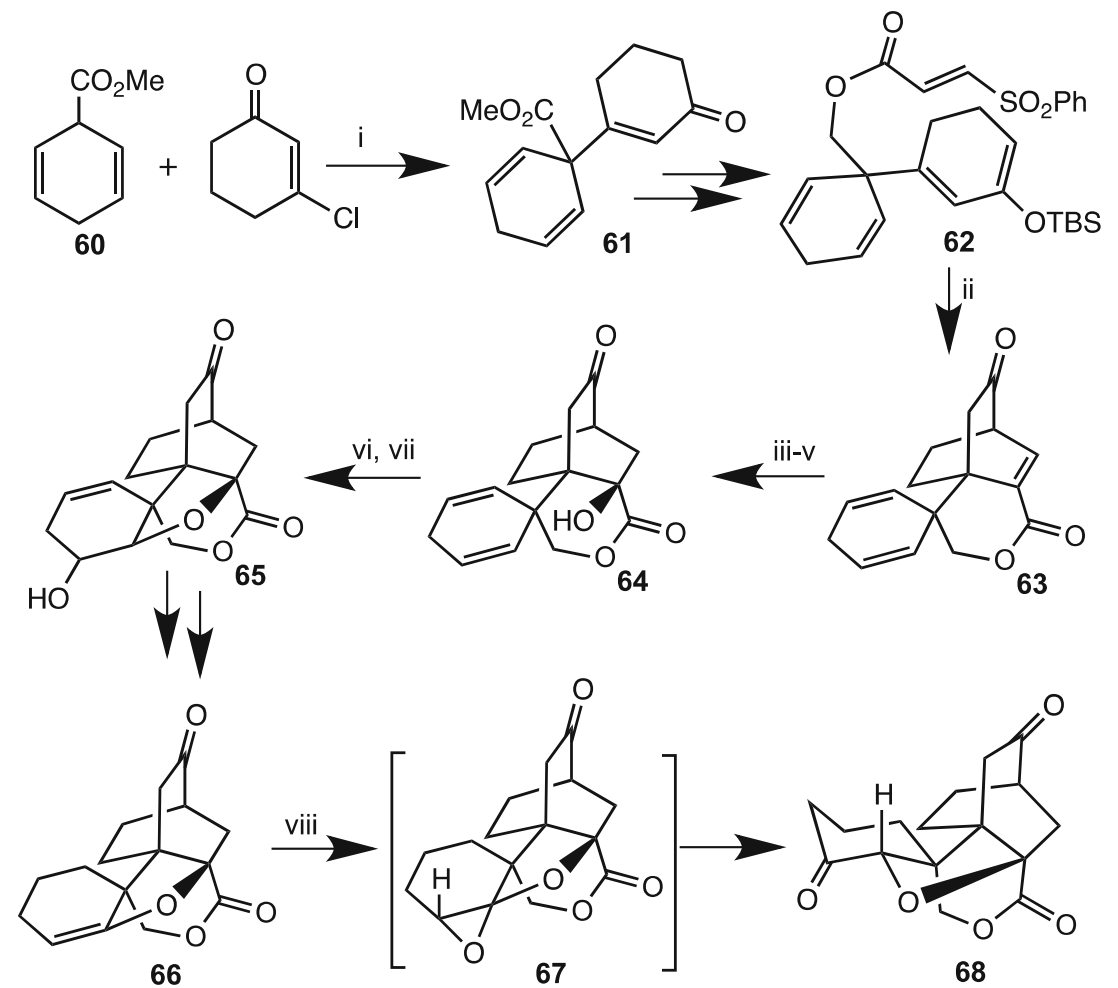

Reagents/conditions: i, LDA, $-78^{\circ} \mathrm{C}$, THF $(40 \%)$; ii, Toluene, sealed tube, $166^{\circ} \mathrm{C}, 1 \mathrm{~h}$, then TBAF, THF $(62 \%)$; iii, $\mathrm{H}_{2} \mathrm{O}_{2}$, $\mathrm{NaOH}, \mathrm{MeOH}, 0^{\circ} \mathrm{C}(95 \%)$; iv, $\mathrm{Mgl}_{2} \mathrm{CH}_{2} \mathrm{Cl}_{2}, 45^{\circ} \mathrm{C}$; v, $\mathrm{Bu}_{3} \mathrm{SnH}-$ AIBN, toulene, reflux (50\% two steps); vi, m-CPBA, $\mathrm{CH}_{2} \mathrm{Cl}_{2}$, rt, $18 \mathrm{~h}(72 \%)$; vii, $p$-TsOH. $\mathrm{H}_{2} \mathrm{O}, \mathrm{CH}_{2} \mathrm{Cl}_{2}, \mathrm{rt}, 1 \mathrm{~h}(90 \%)$; viii, DMDO, $\mathrm{CH}_{2} \mathrm{Cl}_{2}, 0^{\circ} \mathrm{C}$, then ether, $\mathrm{BF}_{3}(75 \%)$.

Scheme 8. Danishefsky's route to pentacyclic core.

furnished tricyclic compound 104. Reaction of 104 with $p$-formaldehyde in the presence of $\mathrm{KO} t \mathrm{Bu}$ followed by removal of protecting group gave the desired precursor 105 (scheme 13).

It is indeed highly remarkable to note that all the 19 carbons of maoecrystal $\mathrm{V}$, bridged bicyclo[2.2.2]octane ring system, spiro-annulated cyclohexane ring, sixmembered lactone, and the five-membered ring ether that is most difficult to construct, are all present in the substrate 105, and unravelled upon dearomatization of phenolic ring and subsequent intramolecular Diels-Alder reaction. Thus, oxidation of $\mathbf{1 0 5}$ with $\mathrm{Pb}(\mathrm{OAc})_{4}$ led to the formation of $\alpha$-acetoxycyclohexa2,4-dienone 106 that underwent intramolecular DielsAlder reaction upon heating to furnish a mixture of adducts from which the desired pentacyclic adduct 107 was isolated in moderate yield (scheme 14). This reaction further demonstrates that oxidative dearomatization of phenols and cycloaddition of the resulting cyclohexadienones is a powerful tool for creation of molecular complexity from aromatics. ${ }^{27-31}$ The adduct
107 was then transformed into maoecrystal $\mathrm{V}$ as presented in scheme 14.

Thus, introduction of allylic hydroxyl group gave the compound 108 that upon treatment with $\mathrm{SmI}_{2}$ furnished product 109 in stereoselective fashion. However, the stereochemistry at C-16 was opposite to that required. Reduction of the double bond and oxidation of hydroxyl group with Dess-Martin periodinane (DMP) gave dione 110. At this juncture, correction of streochemical orientation of methyl group at $\mathrm{C} 16$ was necessary. This was easily done by epimerization. Thus, the compound 110 was refluxed in the presence of DBU that gave a 1:1 mixture of diastereomers (at C16) from which maoecrystal V 1 was isolated (scheme 14).

\subsection{Danishefsky's synthesis}

Sustained efforts made by Danishefsky's group also culminated in the total synthesis of maoecrystal that was reported recently. ${ }^{20}$ Intermediate $\mathbf{6 5}$ was prepared 
<smiles>C=CC(C)(C)COc1ccc2c(c1C(=N)C(C)=O)OCO2</smiles>

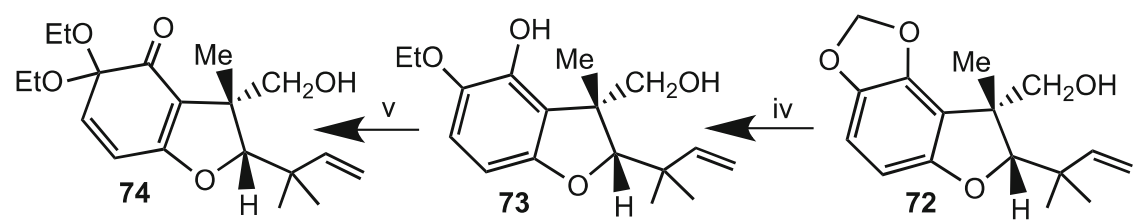

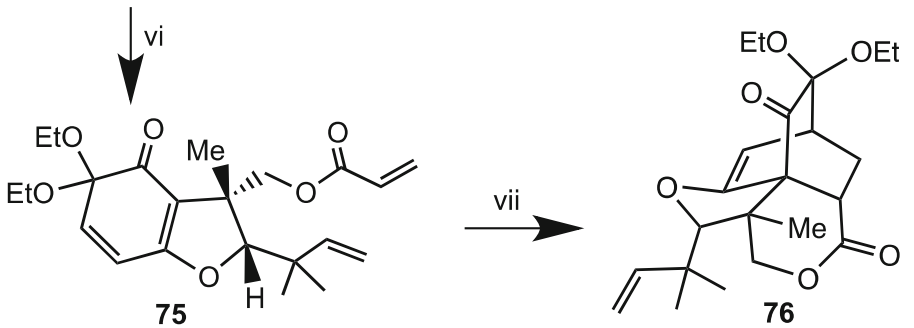

Reagents/conditions: i, $\mathrm{Rh}_{2}(\mathrm{OAc})_{4}, 4 \mathrm{~A} \mathrm{MS}, \mathrm{CH}_{2} \mathrm{Cl}_{2}(86 \%)$; ii, $\mathrm{LiN}\left(\mathrm{SiMe}_{3}\right)_{2}$, $\mathrm{Et}_{2} \mathrm{Zn}, \mathrm{Mel}, \mathrm{DMPU}$, THF (quant.); iii, $\mathrm{LiAlH}_{4}, \mathrm{THF}(63 \%)$; iv, MeMgBr, THF, benzene, $80^{\circ} \mathrm{C}$ (quant.); v, $\mathrm{Phl}\left(\mathrm{OCOCF}_{3}\right)_{2}, \mathrm{NaHCO}_{3}$, $\mathrm{EtOH}(95 \%)$; vi, DMAP, i- $\mathrm{Pr}_{2} \mathrm{NEt}, \mathrm{CH}=\mathrm{CHCOCl}(73 \%)$; vii, $\mathrm{BHT}, \mathrm{o}-\mathrm{DCB}, 140^{\circ} \mathrm{C}, 2 \mathrm{~h}, 160^{\circ} \mathrm{C}$ $12 \mathrm{~h}(98 \%)$.

Scheme 9. Zakarian's route to pentacyclic system.

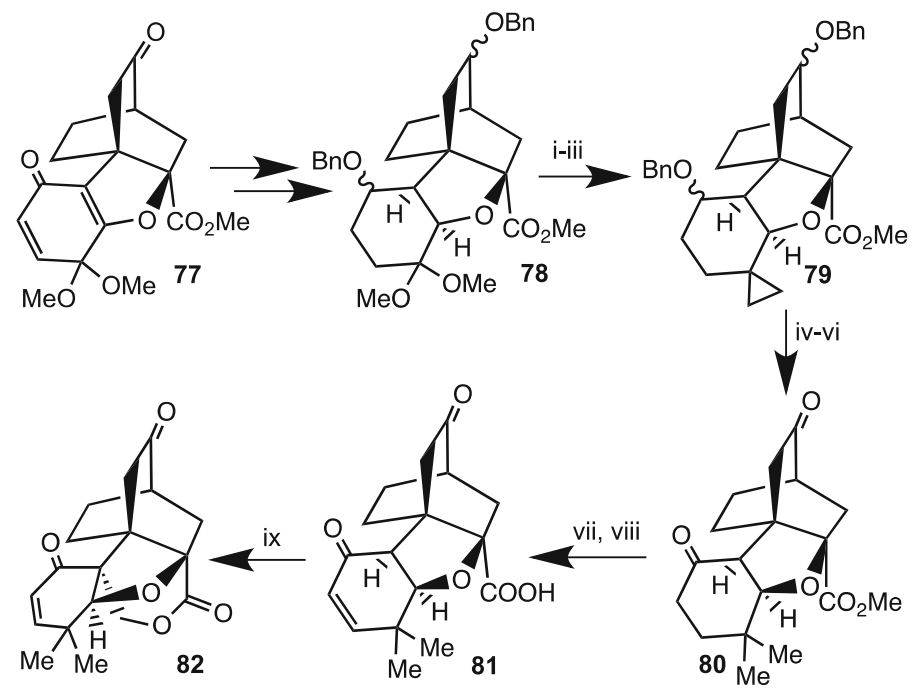

Reagents/conditions: i, TFA, $\mathrm{CH}_{2} \mathrm{Cl}_{2} 0^{\circ} \mathrm{C}, 1 \mathrm{~h}(90 \%) ;$ ii, Tebbe reagent, Toluene/Pyridine $0^{\circ} \mathrm{C}, 1 \mathrm{~h}(78 \%)$; iii, $\mathrm{Et}_{2} \mathrm{Zn}, \mathrm{CH}_{2} \mathrm{I}_{2}$, Toluene, $40^{\circ} \mathrm{C}, 2 \mathrm{~h}(95 \%)$, iv, $\mathrm{Pd}(\mathrm{OH})_{2}, \mathrm{H}_{2}, \mathrm{MeOH}, 25^{\circ} \mathrm{C}, 2 \mathrm{~h}(87 \%)$; v, DMP, $\mathrm{CH}_{2} \mathrm{Cl}_{2}, 25^{\circ} \mathrm{C}, 5 \mathrm{~h}(86 \%)$; vi, $\mathrm{PtO}_{2}, \mathrm{H}_{2}, \mathrm{AcOH}, 40^{\circ} \mathrm{C}, 1 \mathrm{~h}(83 \%)$; vii, TMSCl, LHMDS, THF, $-78^{\circ} \mathrm{C}$, $\mathrm{Pd}\left(\mathrm{CO}_{2} \mathrm{CF}_{3}\right)_{2}, \mathrm{CH}_{3} \mathrm{CN}, 23^{\circ} \mathrm{C}, 8 \mathrm{~h}(52 \%) ;$ viii, $\mathrm{NaOH}, \mathrm{THF}-\mathrm{EtOH}, 70^{\circ} \mathrm{C}, 8 \mathrm{~h}$ (75\%); ix, $\mathrm{KOtBu}, \mathrm{ICH}_{2} \mathrm{Cl}, 18-C r o w n-6, \mathrm{THF}, 70^{\circ} \mathrm{C}, 8 \mathrm{~h}(23 \%)$.

Scheme 10. Chen's synthesis of pentacyclic core. 


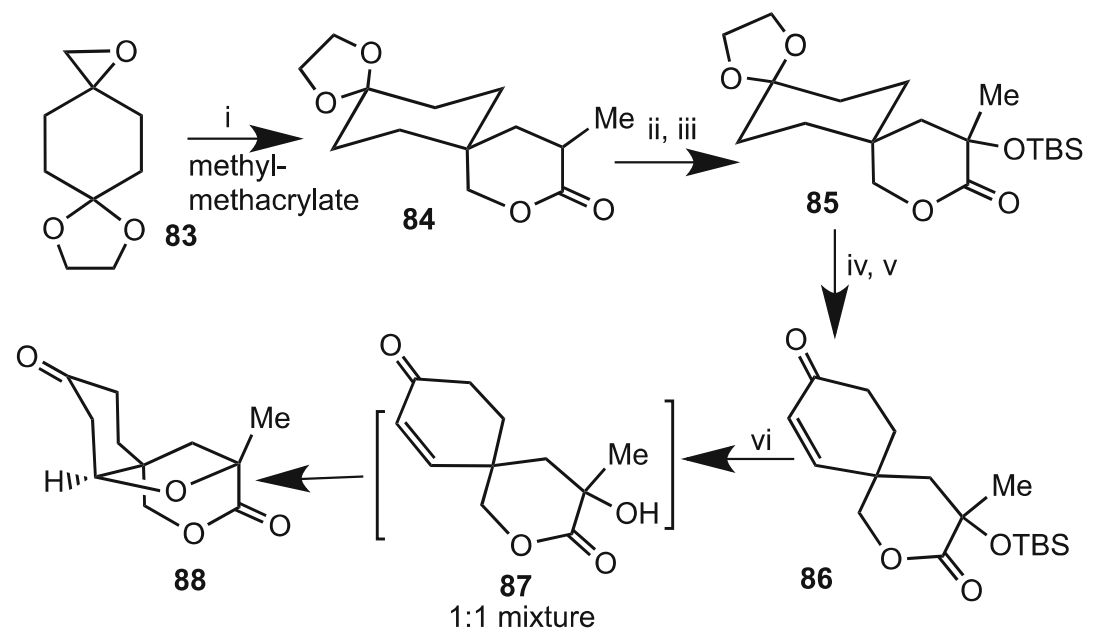

Reagents/conditions: i, $\mathrm{Cp}_{2} \mathrm{Ti}(\mathrm{III}) \mathrm{Cl}(33-54 \%) ; \mathrm{ii}, \mathrm{LiHMDS}, \mathrm{MoOPh}$ (61\%); iii, TBSOTf, 2,6-lutidine (83\%); iv, TsOH (99\%); v, LDA, TMSCl, Pd (OAc) 2 (75\%); vi, TBAF, AcOH, THF.

Scheme 11. Thomson's route to tricyclic fragment.
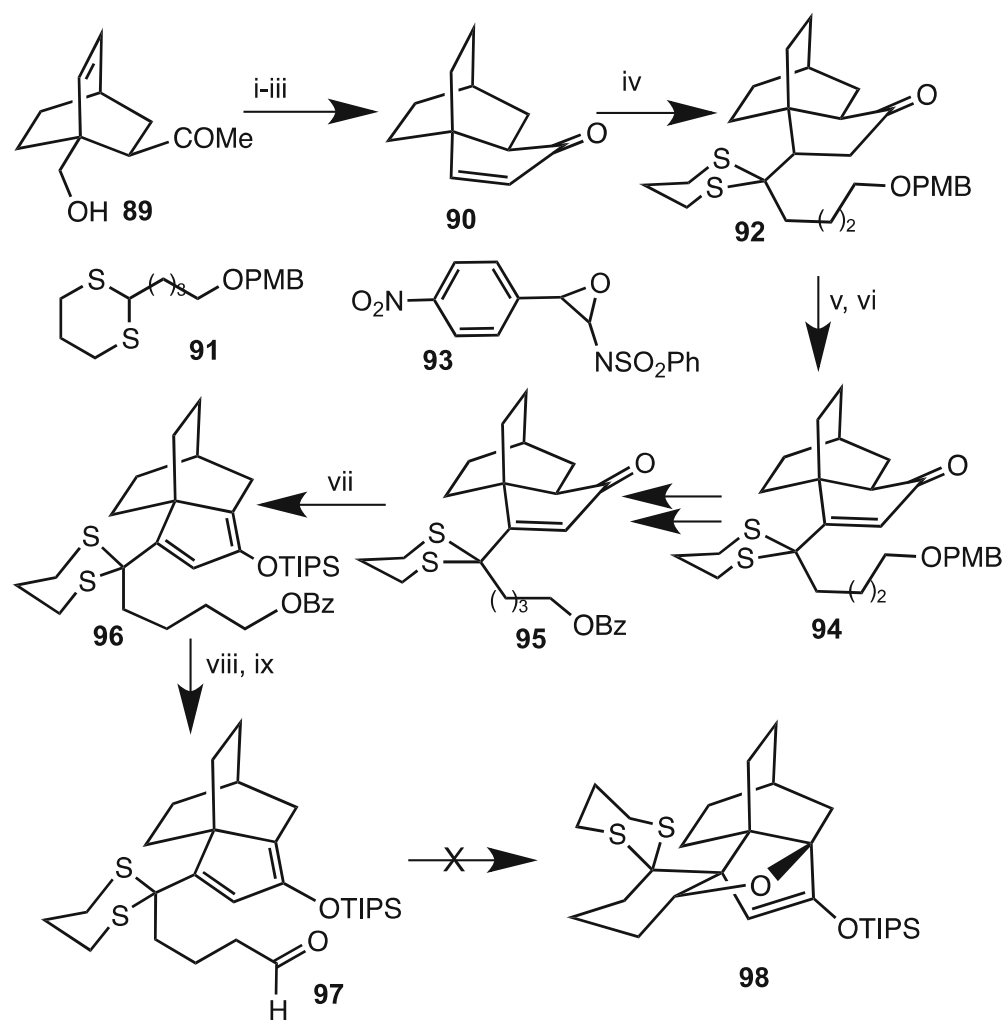

Reagents/conditions: i, PCC, silica gel $\mathrm{CH}_{2} \mathrm{Cl}_{2} ; \mathrm{ii}, \mathrm{H}_{2}$, Pd-C, ether/ ethanol; iii, KOH, aq. THF (46\% three steps); iv, BuLi, 91, HMPA, THF $-78^{\circ} \mathrm{C},(48 \%)$; v, LiHDMS, THF $-78^{\circ} \mathrm{C}$, PhSeBr; vi, 93, $\mathrm{NaHCO}_{3}$, $\mathrm{CH}_{2} \mathrm{Cl}_{2}, \mathrm{H}_{2} \mathrm{O}$ (48\% both steps); vii, TIPSOTf, $\mathrm{Et}_{3} \mathrm{~N}$, THF (95\%); viii, $\mathrm{LiEt}_{3} \mathrm{BH}$. THF; ix, Dess-Martin, $\mathrm{NaHCO}_{3}, \mathrm{CH}_{2} \mathrm{Cl}_{2}$ (79\% two steps).

Scheme 12. Chisholm's route to pentacyclic core. 


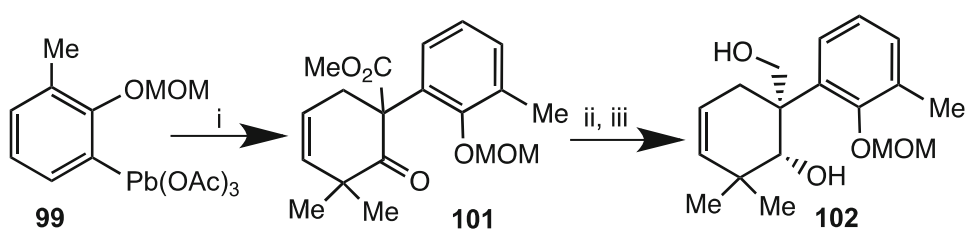

99<smiles>COC(=O)C1CC=CC(C)(C)C1=O</smiles><smiles>CC(C)CC(C)(C)C</smiles><smiles>C=C(OC[C@]1(c2cccc(C)c2O)CC=CC(C)(C)[C@@H]1OC(C)(C)C)C(=O)O</smiles><smiles>CCOC(=O)C1OC(=O)OC[C@@]2(c3cccc(C)c3OC)CC=CC(C)(C)[C@@H]2OC1=O</smiles><smiles>CCOC(=O)N=C(C(=O)OCC)[C@]1(c2cccc(C)c2OC)CC=CC(C)(Cl)[C@H]1O</smiles>

Reagents/conditions: i, Pyridine, $100, \mathrm{CHCl}_{3}, 60^{\circ} \mathrm{C}(88 \%)$; ii, $(\mathrm{Bu})_{4} \mathrm{NBH}_{4}$ methanol (65\%); iii, $\mathrm{LiAlH}_{4}$, THF, rt (88\%); iv, 2-(diethoxyphosphoryl)acetic acid, EDCl, DMAP, $\mathrm{CH}_{2} \mathrm{Cl}_{2}$, rt (82\%); v, $\mathrm{TsN}_{3}, \mathrm{DBU}, 0^{\circ} \mathrm{C}(81 \%)$; vi, $\mathrm{Rh}_{2}(\mathrm{OAc})_{2}$, benzene, $\Delta(60 \%)$; vii, $\mathrm{KOtBu},(\mathrm{HCHO}) \mathrm{n} \mathrm{THF}, 0^{\circ} \mathrm{C}(95 \%)$; viii, TFA, $\mathrm{CH}_{2} \mathrm{Cl}_{2}$, rt (90\%).

Scheme 13. Synthesis of embellished precursor 105.

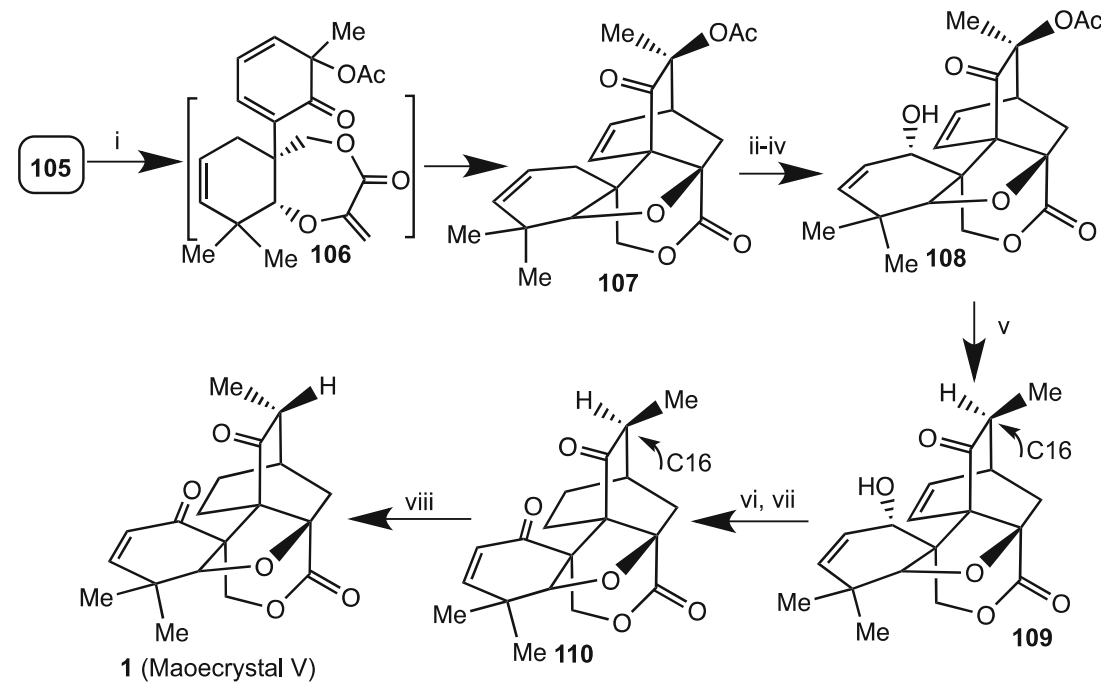

Reagents/conditions: i, $\mathrm{Pb}(\mathrm{OAc})_{4}, \mathrm{AcOH}, 0^{\circ} \mathrm{C}$ then toluene $145^{\circ} \mathrm{C}$ (36\%); ii, NBS, $\left(\mathrm{Ph}_{2} \mathrm{CO}_{2}\right) \mathrm{O}, \mathrm{CCl}_{4}$, reflux, $2 \mathrm{~h}(90 \%)$; iii, $\mathrm{Bu}_{3} \mathrm{SnH}$, TEMPO, benzene, reflux, $2 \mathrm{~h},(75 \%)$; iv, $\mathrm{Zn}, \mathrm{AcOH}, \mathrm{THF}-\mathrm{H}_{2} \mathrm{O}, 70^{\circ} \mathrm{C}$, $2 \mathrm{~h},(85 \%) ; \mathrm{v}, \mathrm{Sml}_{2}$, THF, $\mathrm{MeOH}$, rt (88\%); vi, Lindlar catalyst, $\mathrm{MeOH}$, THF, rt, 2 h (92\%); vii, DMP, $\mathrm{CH}_{2} \mathrm{Cl}_{2}$, rt, 1 h (88\%); viii, DBU, toluene, $100^{\circ} \mathrm{C}, 1 \mathrm{~h}(48 \%)$.

Scheme 14. Synthesis of maoecrystal V by Yang and co-workers. ${ }^{19}$

as described previously and elaborated into maoecrystal (schemes 15 and 16). Transformation of $\mathbf{6 5}$ into maoecrystal required correction of stereogenic centre at C5 and manipulation of spiroannulated six-membered ring and introduction of a methyl group $\alpha$-to the carbonyl group. Thus, the pentacyclic intermediate $\mathbf{6 5}$ was converted into hydroxyl-acetate 111. Protection of hydroxyl group as MOM ether followed by hydrolysis of acetate afforded compound $\mathbf{1 1 2}$ that upon epoxidation furnished 113. Treatment of 113 with Dess-Martin periodinane (DMP) followed by chromatography on $\mathrm{SiO}_{2}$ and acylation gave 


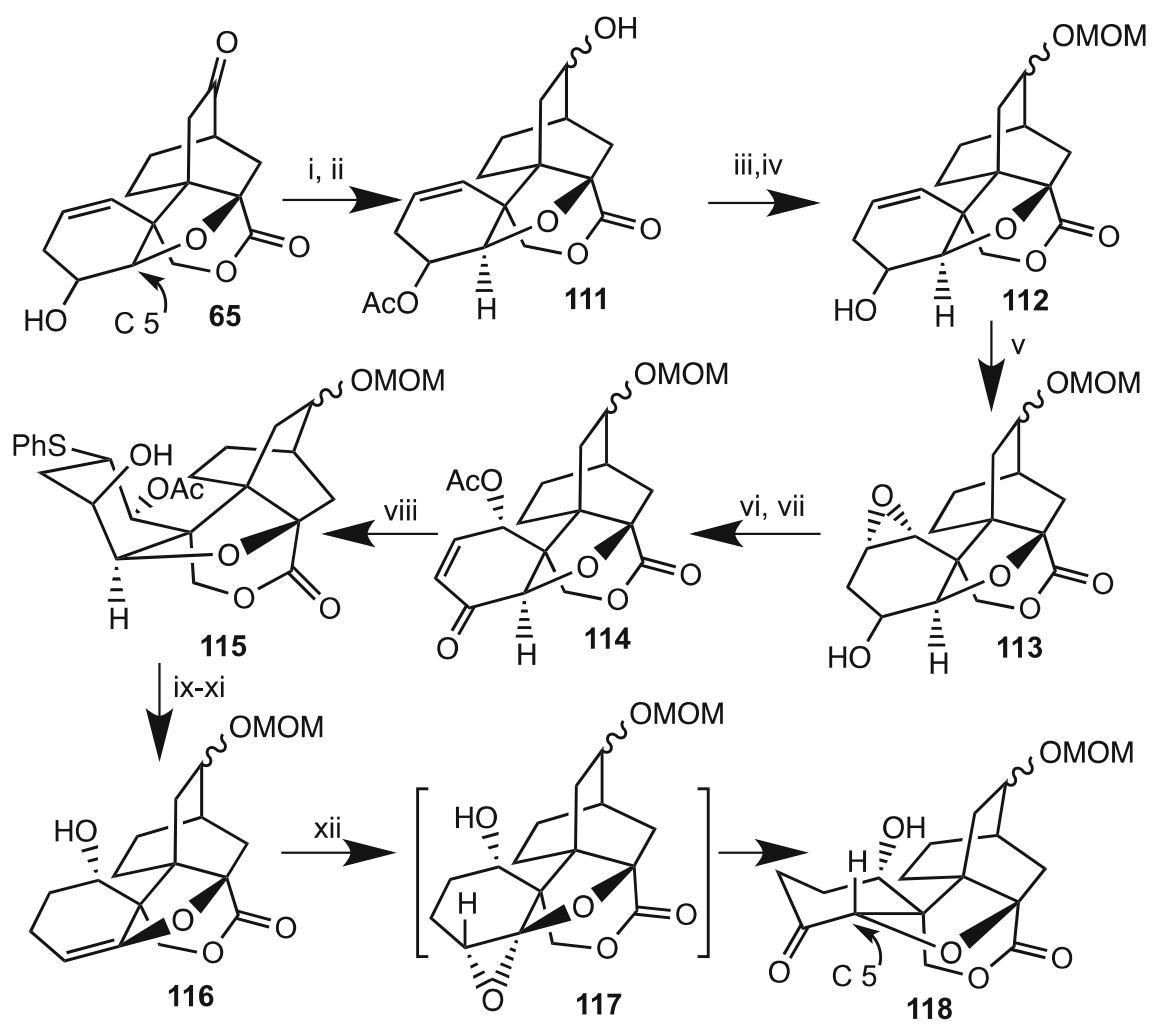

Reagents/conditions: i, $\mathrm{Ac}_{2} \mathrm{O}, \mathrm{Py}, \mathrm{CH}_{2} \mathrm{Cl}_{2}$; ii, $\mathrm{NaBH}_{4}, \mathrm{CH}_{2} \mathrm{Cl}_{2}$ /ethanol (85\% two steps); iii, $\mathrm{MOMCl}, i-\mathrm{Pr}_{2} \mathrm{EtN}$; iv, $\mathrm{K}_{2} \mathrm{CO}_{3}, \mathrm{MeOH}(90 \%$ two steps); v, $m$-CPBA, rt (95\%); vi, DMP, $\mathrm{NaHCO}_{3}, \mathrm{CH}_{2} \mathrm{Cl}_{2}, 0^{\circ} \mathrm{C}(85 \%)$; vii, $\mathrm{Ac}_{2} \mathrm{O}, \mathrm{Py}, \mathrm{CH}_{2} \mathrm{Cl}_{2}(90 \%)$; viii, $\mathrm{PhSH}, \mathrm{Et}_{3} \mathrm{~N}$, then $\mathrm{NaBH}_{4}, \mathrm{EtOH}$, $\mathrm{CH}_{2} \mathrm{Cl}_{2}$ (78\%); ix, Raney Ni; $\mathrm{x}, \mathrm{MsCl}$, DMAP (65\%, two steps); $\mathrm{xi}$, $\mathrm{K}_{2} \mathrm{CO}_{3}, \mathrm{MeOH}$, rt (95\%); xii, DMDO, then $\mathrm{BF}_{3}$. OEt 2 (82\%).

Scheme 15. Synthesis of pentacyclic intermediate 118.
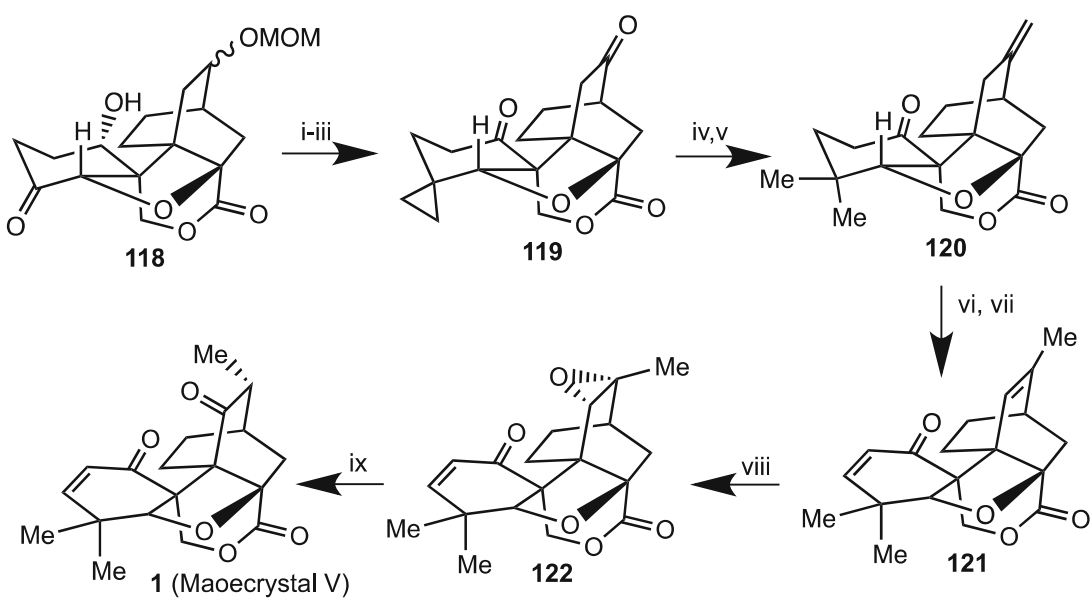

Reagents/conditions: i, Lombardo reagent, $\mathrm{CH}_{2} \mathrm{Cl}_{2}$, rt (85\%); ii, $\mathrm{CH}_{2} \mathrm{I}_{2}, \mathrm{Zn} / \mathrm{Ag}$, ether (88\%); iii, $\mathrm{PCC}, \mathrm{CH}_{2} \mathrm{Cl}_{2}$, rt (76\%); iv, $\mathrm{H}_{2}, \mathrm{PtO}_{2}$, AcOH (40\%); v, Lombardo reagent, $\mathrm{CH}_{2} \mathrm{Cl}_{2}, 0^{\circ} \mathrm{C}(80 \%)$; vi, p-TsOH. $\mathrm{H}_{2} \mathrm{O}$, benzene, $76^{\circ} \mathrm{C}(85 \%)$; vii, LDA, TMSCl, THF, $-78^{\circ} \mathrm{C}$ $(90 \%)$, then $\mathrm{Pd}(\mathrm{TFA})_{2}, \mathrm{CH}_{3} \mathrm{CN}(80 \%)$; viii, TFDO, $\mathrm{CH}_{2} \mathrm{Cl}_{2},-78^{\circ} \mathrm{C}$ to $0^{\circ} \mathrm{C}(90 \%)$; ix, $\mathrm{BF}_{3} . \mathrm{OEt}_{2}, \mathrm{CH}_{2} \mathrm{Cl}_{2}$, rt (85\%).

Scheme 16. Synthesis of maoecrystal V by Danishefsky and Peng. ${ }^{20}$ 
acetoxy-enone 114. 1,4-Addition of thiophenol followed by reduction of the carbonyl group gave compound 115 that was converted into enol ether $\mathbf{1 1 6 .}$ Epoxidation of $\mathbf{1 1 6}$ to $\mathbf{1 1 7}$ followed by Lewis acid catalysed stereoselective rearrangement furnished the pentacyclic compound $\mathbf{1 1 8}$ having correct stereochemistry at $\mathrm{C} 5$.

The intermediate 118 was then elaborated into diketo-lactone 119 containing spirocyclopropane ring in three steps. Olefination of $\mathbf{1 1 8}$ using Lombardo reagent followed by Simon-Smith reaction and subsequent oxidation gave diketolactone 119. Interestingly, methoxymethyl (MOM) ether was converted into methoxyethyl (MOE) due to $\mathrm{CH}_{2}$ insertion during cyclopropanation step, which was cleaved during the oxidation step. Reduction of cyclopropane ring and olefination gave compound $\mathbf{1 2 0}$ that was converted into dienone 121. Regioselective epoxidation of $\mathbf{1 2 0}$ gave a diasteromeric mixture of two epoxides from which compound 122 was isolated. Lewis-catalysed rearrangement of epoxide ring furnished $( \pm$ )-maoecrystal $\mathrm{V}$ (scheme 16).

\section{Conclusion}

We have presented synthetic efforts towards maoecrystal V. Various kinds of ingenious strategy and tactics were employed to construct framework of maoecrystal V. It appears that creation of spiro-annulated lactone and five-membered ether ring, quaternary centres and functionality poses significant problems. Groups led by Yang and Danishefsky successfully completed the synthesis of $( \pm)$-maoecrystal $\mathrm{V}$ in a highly unique fashion. While these achievements are remarkable feats, synthesis of natural optically pure (-)-maoecrystal remains a challenge.

\section{Acknowledgements}

VS thanks the Department of Science and Technology (DST), New Delhi for J C Bose National fellowship and IIT Bombay for chair Professorship. TKB and NI are thankful to the Council of Scientific and Industrial Research (CSIR), New Delhi for providing fellowship.

\section{References}

1. Newman D J and Cragg G M 2007 Nat. Prod. Rep. 70 461

2. Genilloud O and Vicente F (eds) 2012 Drug discovery from natural products, Royal Society of Chemistry, Thomas Graham House, Science Park, Milton Road, Cambridge CB4 OWF, UK, 2012
3. (a) Wang J, Kodali S, Lee S H, Galgoci A, Painter R, Dorso K, Racine F, Motyl M, Hernandez L, Tinney E, Colletti S L, Herath K, Cummings R, Salazar O, Gonzalez I, Basilio A, Vicente F, Genilloud O, Pelaez F, Jayasuriya H, Young K, Cully D and Singh S B 2007 Proc. Natl. Acad. Sci. USA 104 7612; (b) Jayasuriya H, Herath K B, Zhang C, Zink D L, Basilio A, Genilloud O, Diez M T, Vicente F, Gonzalez I, Salazar O, Pelaez F, Cummings R, Ha S, Wang J and Singh S B 2007 Angew. Chem. Int. Ed. 46 4684

4. Wani M, Taylor H, Wall M, Coggon P and McPhail A 1971 J. Am. Chem. Soc. 932325

5. Sun H D, Xu Y L and Jiang B 2001 Diterpenoids from Isodon species, Beijing, China: Science Press October

6. Li S-H, Wang J, Niu X-M, Shen Y-H, Zhang H-J, Sun H-D, Li M, Tian Q-E, Lu Y, Cao P and Zheng Q-T 2004 Org. Lett. 64327

7. Gong J, Lin G, Li C C and Yang Z 2009 Org. Lett. 11 4770

8. Krawczuk P J, Schone N and Baran P S 2009 Org. Lett. 114774

9. Peng F, Yu M and Danishefsky S J 2009 Tetrahedron Lett. $\mathbf{5 0} 6586$

10. Nicolaou K C, Dong L, Deng L, Talbot A C and Chen D Y-K 2010 Chem. Commun. 4670

11. Singh V, Bhalerao P and Mobin S M 2010 Tetrahedron Lett. 513337

12. Lazarski K E, Hu D X, Stern C L and Thomson R J 2010 Org. Lett. 123010

13. Baitinger I, Mayer P and Trauner D 2010 Org. Lett. 12 5656

14. Peng F, Yu M and Danishefsky S J 2011 Tetrahedron Lett. 522104

15. Gu Z and Zakarian A 2011 Org. Lett. 131080

16. Dong L, Deng L, Lim Y H, Leung G Y, Chen C and Chen D Y-K 2011 Chem. Eur. J. 175778

17. Lazarski K E, Akpinar B and Thomson R J 2013 Tetrahedron Lett. 54635

18. Carbarry P, Viernes D R, Choi L B, Fegley M W and Chisholm J D 2013 Tetrahedron Lett. 54 1734

19. Gong J, Lin G, Sun W, Li C C and Yang Z 2010 J. Am. Chem. Soc. 13216745

20. Peng F and Danishefsky S J 2012 J. Am. Chem. Soc. 51 18860

21. Elliot G I, Konopelski J P and Olmstead M M 1999 Org. Lett. 11867

22. (a) Zibral E, Wessely F and Sturn H 1962 Monatsch Chem. 93 15; (b) Zibral E, Wessely F and Lahrmann E 1961 Monatsch Chem. 92654

23. Fox J M, Huang X, Chieffi A and Buchwald S 2000 J. Am. Chem. Soc. 1221360

24. Tanaka D and Myers A G 2004 Org. Lett. 6 433

25. (a) Adler E, Bransen S and Miyake H 1971 Acta Chem. Scand. 25 2055; (b) Singh V, Porinchu M, Vedantham P and Sahu P K 2005 Organic Synthesis 81171

26. (a) Pellissier H 2005 Tetrahedron 61 6479; (b) Shimada N, Stewart C and Tius M A 2011 Tetrahedron 675851 
27. (a) Quideau S, Pouysegu L and Deffieux D 2008 Synlett 467; (b) Pouysegu L, Chassaing S, Dejugnac D, Lamidey A-M, Miqueu K, Sotiropoulos J-M and Quideau S 2008 Angew. Chem. Int. Ed. 473552

28. (a) Luo S-Y, Jang Y-J, Liu J-Y, Chu C-S, Liao C-C and Hung S-C 2008 Angew. Chem. Int. Ed. 47 8082; (b) Liao C-C and Peddinti R K 2002 Acc. Chem. Res. 35 856
29. Magdziak D, Meek S J and Pettus T R R 2004 Chem. Rev. 1041383

30. Roche S P and Porco Jr J A 2011 Angew. Chem. Int. Ed. 504068

31. (a) Singh V 1999 Acc. Chem. Res. 32 324; (b) Singh V, Praveena G D, Karki K and Mobin S M 2007 J. Org. Chem. 72 2058; (c) Singh V, Sahu P K, Sahu B C and Mobin S M 2009 J. Org. Chem. 746092 